\title{
Benchmarking International Trade Performance of OECD Countries: TOPSIS and AHP Approaches ${ }^{1}$
}

\author{
OECD Ülkelerinin Uluslararasi Ticaret Performans Değerlendirmesi: \\ TOPSIS ve AHP Yaklaşımları \\ Can KARABIYIK* \\ Büşra KUTLU KARABIYIK**
}

\begin{abstract}
Economic performance of countries has been evaluated on several counts from both microeconomic and macroeconomic framework in many empirical studies by using many quantitative technics such as "Multi Criteria Decision Making" methods. After all, this paper has the characteristic of first research which examines international trade performance. Today, governments as well as firms are seeking new opportunities to take a bigger share of global market through trade by managing scarce resources, trade agreements and arrangements, making innovation, increasing productivity et cetera. It is within this context that the authors aim at evaluating international trade performance of OECD countries by using TOPSIS and AHP approaches between 1999-2014 in the light of three foreign trade performance indicators, namely; Volume of Exports Per Capita, Normalized Trade Balance and Terms of Trade. Our findings indicate that Norway, Ireland and Germany are ranked among the top three countries while Turkey, USA and the Greece are the bottom three.
\end{abstract}

Key Words: Macroeconomics, International Trade Performance, Multi Criteria Decision Making, TOPSIS, AHP.

$\ddot{O} z$

Ekonomilerin ekonomik performansları "Çok Kriterli Karar Verme" yöntemleri gibi çeşitli kantitatif teknikler kullanılarak hem makroekonomik hem de mikroekonomik açıdan çok sayıda ampirik çalışmada değerlendirilmiştir. Buna karşın, bu araştırma ülkelerin uluslararası ticaret performanslarını ampirik olarak karşılaştıran ilk araştırma özelliğini taşımaktadır. Günümüzde firmalar gibi hükümetler de dış ticaret vasıtasıyla kıt kaynak yönetimi, dış ticaret anlaşmaları ve düzenlemeleri, inovasyon, verimlilik artırımı vb. stratejiler izleyerek küresel piyasadan daha büyük bir pay alabilmek için yeni firsatlar kollamaktadırlar. Bu araştırma, OECD ülkelerinin 1999-2014 yılları arasındaki uluslararası ticaret performanslarını Kişi Başı İhracat Hacmi, Normalleştirilmiş Ticaret Dengesi ve Ticaret Hadleri değişkenlerini kullanarak TOPSIS ve AHP yaklaşımları yardımıyla incelemeyi amaçlamaktadır. Araştırmada elde edilen bulgular göstermektedir ki; Norveç, İrlanda ve Almanya uluslararası ticaret performansı değerlendirmesinde ilk üç sırayı alırken Türkiye, ABD ve Yunanistan son üç sırada yer almışlardır.

Anahtar Kelimeler: Makroekonomi, Uluslararası Ticaret Performansı, Çok Kriterli Karar Verme, TOPSIS, AHP.

\section{Introduction}

Comparative advantages and the specialization theories which developed by David Ricardo and Adam Smith emphasize the importance of international trade. They state that foreign trade is one of the constituents of a nation's wealth and everybody can be winner by taking part in it. Foreign trade has crucial role on economic growth performance of both emerging and advanced countries by encouraging technological innovation, increasing the level of specialization through division of labor and improving efficiency of domestic and foreign investments. For these reasons foreign trade performance, indicator of comparative advantages and international specialization represent country's productivity level. Moreover, foreign trade may measure competitive power of an economy which illustrates its macroeconomic performance. In addition to this, national competitiveness shows creative, productive and

\footnotetext{
${ }^{1}$ Bu çalışma 2016 yılında ABSRC (Advances in Business-Related Scientific Research Conference) Venedik Konferansı'nda bildiri olarak sunulmuş ve tam metin olarak hiçbir yerde yayınlanmamıştır.

* Arş.Gör., Celal Bayar Üniversitesi, İIBF, c_karabiyik@ hotmail.com.

** Arş.Gör., Adnan Menderes Üniversitesi, Söke İşletme Fakültesi, Yönetim Bilişim Sistemleri, busrakutlu@hotmail.com.
} 
distributive skills of an economy in foreign trade during gaining increasing returns on its own factor endowment (Scott \& Lodge, 1985).

In phase with the bottom lines of the classical, neoclassical and new international trade theories, foreign trade constitutes an identifier element affecting economic growth of individual economies and global economy (Jeníček, 2003). Neo-Kaldorian approach suggests that liveliness of exportation activities may stimulate economic growth through its aggregate demand growing effect and also scale economies that consequence of speed-up in production (Araujo \& Trigg, 2015). International trade alters the sucture of national manufacturing as well as in accordance with requested area of utilization with regard to country's factor endowment (Krepl \& Jeníček, 2009). There is also interrelation between foreign trade and total factor productivity. Trade is significant determinant for long-term total factor productivity through its advanced equipment supplying property from industrial countries to developing countries (Teixeira \& Fortuna, 2010). Additionally trade openness may increase country's chance to take advantage from R\&D opportunities and innovations of foreign countries (Lichtenberg, Pottelsberghe, \& Potterie, 1998). Beside these, on one hand international trade can affect living standards by providing large variety of products to consumers from different countries, increasing capacity and employment and removing price differences among countries. On the other hand exporter firms precede non-exporter firms in productivity (Alvarez \& López, 2005). Additionally, information development and transfer allow firms to come in possession of worldwide pro-active and prosperous. Business operations, such as $\mathrm{R} \& \mathrm{D}$, innovation and information transfer substantially interact with microeconomic foreign trade performance (Grossman \& Helpman, 1989). In a nutshell international trade plays an essential role in a country in terms of microeconomic perspective as well as macroeconomic context. Because of these reasons, evaluation of foreign trade performances among different economies may enlighten our prospect to the countries.

Macroeconomic performances of countries can be compared by using several techniques and findings that acquired as an output of empirical analyses are accepted as economic performances of countries for particular time periods. Decision makers should appraise a finite number of alternatives to obtain most convenient one by categorizing them into predetermined homogeneous clusters and ordering them accordingly with their ranking scores by means of related criteria (Zavadskas \& Turskis, 2011). Multi Criteria Decision Making (MCDM) methods that benchmark alternatives by evaluating more than one factor enable researchers to select most appropriate one among alternatives and they are frequently used to compare such organizations (Urfalioğlu \& Genç, 2013).

MCDM methods can procure a miscellaneous evaluation by taking more than one foreign trade performance measures into account and allow for more inclusive analysis than fundamental methods. In this study we assess international trade performance of OECD Countries by using TOPSIS and AHP methods in consideration of three indicators namely; Volume of Exports Per Capita, Normalized Trade Balance and Terms of Trade for the period of 1999-2014.

The paper is organized as follows: after the introduction section, the second section provides a literature review while data, methodology and the empirical results are given in the following section. Finally, the last section concludes the paper.

\section{Literature Review}

Performance of economic organizations has been evaluated on several counts from both microeconomic and macroeconomic perspectives in many empirical researches by using a variety of approaches such as MCDM methods, after all this study has the feature of first research that examines international trade performance. 
Eleren \& Karagül (2008) investigate economic performance of Turkey between 1986 and 2006 by using TOPSIS methodology by employing seven macroeconomic indicators namely economic growth rate, current account deficit, total national debt, consumer price index, current account balance, sovereign spread and unemployment rate. They conclude that 1986 is the best year in terms of economic performance, while 1999, 2000, 2001 and 2006 are among worst years as a result of national and global crises. Mangır \& Erdoğan (2011) analyze effects of global financial crisis on Italy, Greece, Spanish, Portugal, Ireland and Turkey during 2002 and 2009. Authors utilize Fuzzy TOPSIS Method and employ some data namely; economic growth rate, inflation rate, unemployment rate, current account balance and lastly budget balance rate to measure macroeconomic performance. They argue that Turkey overcomes global financial crisis with relatively lower losses by comparison with other five countries. Urfalioğlu \& Genç (2013) compare economic performance of Turkey and European Union countries by using ELECTRE, TOPSIS and PROMETHEE methods and cross-section data of 2010. They select GDP per capita, economic growth rate, export, import, employment and inflation rate as indicator for economic performance. They claim that results of these three methods have the same trend and countries with best performances are similar according to all models. The results of their TOPSIS analysis indicate that Turkey is ranked as thirty-first among European Union countries. Moreover, Mandic et al. (2014) evaluate performance of banks by employing Fuzzy AHP and TOPSIS methods. They use following financial indicators; equity, portfolio, sources, liquid assets, cash, net interest income, core business net income and earnings before tax to determine best performing financial intermediary institution in Serbian banking sector between 2005 and 2010. They find that Banca Intesa has the best ranking. Eyüboğlu (2015) compares macro performances of developing countries such as Turkey, Poland, Mexico, Chile, Malaysia, Hungary, Indonesia, China, Argentina and Brazil by employing TOPSIS-AHP couple and using the data of economic growth rate, inflation rate, unemployment rate and the current account balance. They suggest that Malaysia and China are the highest performance countries between 2003 and 2013. Wanke et al. (2016) utilize TOPSIS approach to examine efficiency of banks in Malaysia for the period of 2009 and 2013 by using personnel expenditure, total business expenditures, asset earnings, deposits, net interest income, business profit and net income to measure performance of institutions. They argue that Maybank Islamic Berhad is the most efficient bank in Malaysia during chosen period.

\section{Data and Methodology}

In this study, Volume of Exports Per Capita, Normalized Trade Balance and Terms of Trade are used to measure international trade performance of OECD countries covering the period between 1999 and 2014. International trade productivity interacts with export performance which can be measured by the Volume of Exports Per Capita (VEPC) (Majerová \& Nevima, 2015). VEPC is measured as total value of exported goods and services (EX) divided by population (POP):

$$
\mathrm{VEPC}=\frac{\mathrm{EX}}{\mathrm{POP}}
$$

Higher levels of exports may not represent productivity in international trade alone because of differences in labor force magnitudes. For this reason, per capita export is more convenient measure. Higher ratio of VEPC indicates higher level of international division of labor and higher earnings from foreign trade. Second international trade indicator, Normalized Trade Balance (TB), can be calculated as trade balance divided by the total value of trade:

$$
\mathrm{TB}=\frac{\mathrm{EX}-\mathrm{IM}}{\mathrm{EX}+\mathrm{IM}}
$$


TB is frequently described as measures of trade specialization and competition power of domestic products, because dispersion of industry-specific balances around the world trade balance pictures the shape of comparative advantages and disadvantageousness of an economy (Iapadre, 2001). TB gives an opportunity to compare economies with different domestic incomes across time and varies in the range of -1 to +1 . When foreign trade is balanced, TB takes the value of zero. Third and last indicator for international trade measure is Terms of Trade $(\mathrm{TT})$ which refers to the ratio of export prices $\left(\mathrm{P}_{\mathrm{EX}}\right)$ to import prices $\left(\mathrm{P}_{\mathrm{IM}}\right)$ :

$$
\mathrm{TT}=\frac{\mathrm{P}_{\mathrm{EX}}}{\mathrm{P}_{\mathrm{IM}}}
$$

TT is widely used to measure international trade gains and losses which resultant from fluctuations in export and import prices. TT is generally accepted measure for improvement in foreign trade and higher TT values than one indicates favorable progress (Krepl \& Jeníček, 2009). Additionally, there is a significant positive relationship between trade and economic growth which is essential for trade performance (Mendoza, 1997). Terms of trade and population data are obtained from the World Development Indicators and export-import data are from the World Trade Organization Statistics Database.

TOPSIS, one of the multivariate decision methods has been used to obtain the country which has the best trade performance between OECD countries. TOPSIS method can easily be applied on raw data set. Therefore, any qualitative transformation for the data set isn't needed. TOPSIS is applied and adapted to many subjects in many different research areas to solve multivariate decision problems. Thus, it was broadly used. TOPSIS method consists of six consecutive stages. These stages can be explained as below:

Step.1: The decision matrix must be created. Alternatives which are wanted to rank by their superiority take place at rows of the matrix and evaluation factors which are going to be used in decision making takes place at columns. A matrix is the beginning matrix which is determined by decision maker. Every $a_{i j}$ in decision matrix represents the real value of the ith alternative according to jth criteria.

$$
A_{i j}=\left[\begin{array}{ccc}
a_{11} & \cdots & a_{1 n} \\
\vdots & \ddots & \vdots \\
a_{m 1} & \cdots & a_{m n}
\end{array}\right]
$$

Step.2: The normalization matrix can be named as NDM (Normalized Decision Matrix) which represents the relative performance of the generated design alternatives. NDM is created via benefits from $\mathrm{A}_{\mathrm{ij}}$ Decision Matrix. There are many normalization process methods. Among them, one of the most common used methods is vector normalization. As described below, every single value in decision matrix is divided by sum of square of the column values which is at same column with the dividend value. The normalized value $\left\{r_{i j}\right\}$ is calculated as

$$
r_{i j}=\frac{a_{i j}}{\sqrt{\sum_{k=1}^{m} a_{k j}^{2}}} R_{i j}=\left[\begin{array}{ccc}
r_{11} & \cdots & r_{1 n} \\
\vdots & \ddots & \vdots \\
r_{m 1} & \cdots & r_{m n}
\end{array}\right]
$$

Step.3: The weights which imply importance of the criteria are defined. In this paper, AHP method is used to find out the weights. By the way of weights of criteria, weighted normalized matrix is obtained. While determining the importance degrees of criteria, the consistency rate of weights are controlled. When consistency rate is bigger than 0.1 , all estimations needed to be reviewed (Supçiller \& Çapraz, 2011). In this paper, "Super Decision" program is employed to apply AHP method. 
Step.4: At this stage, normalized matrix is multiplied with the weights of criteria. By this way, $\mathrm{V}_{\mathrm{ij}}$ matrix which represents Weighted Decision Matrix can be obtained.

$$
V_{i j}=\left[\begin{array}{ccc}
w_{1} r_{11} & \cdots & w_{n} r_{1 n} \\
\vdots & \ddots & \vdots \\
w_{1} r_{m 1} & \cdots & w_{n} r_{m n}
\end{array}\right]
$$

Step.5: Positive and negative ideal solutions are detected. Positive ideal solutions $\left(\mathrm{A}^{+}\right)$ and negative ideal solutions $\left(\mathrm{A}^{-}\right)$are acquired according to the Weighted Decision Matrix (Vij). Positive ideal solutions and negative ideal solutions are consists of the highest and the lowest values of rows at $\mathrm{V}_{\mathrm{ij}}$ respectively.

$$
A^{*}=\left\{\left(\max _{i} v_{i j} \mid j \in J\right),\left(\min _{i} v_{i j} \mid j \in J^{\prime}\right\} \quad A^{-}=\left\{\left(\min _{i} v_{i j} \mid j \in J\right),\left(\max _{i} v_{i j} \mid j \in J^{\prime}\right\}\right.\right.
$$

The distance is evaluated to positive ideal solution and to negative ideal solution. Final ranking for decision making will be obtained by comparing distances.

Step.6: The separation distance of each competitive design alternative from the positive ideal solution and the negative ideal solution is measured. Euclidean distance method is applied in this paper. Every alternative's distance to the best performed value $\left(v_{j}^{+}\right)$and to the worst performed value $\left(v_{j}^{-}\right)$are calculated (Özcan, Elebi, \& Esnaf, 2011). These values are named as $\mathrm{S}^{+}$and $\mathrm{S}^{-}$respectively.

$$
S_{i}^{+}=\sqrt{\sum_{j=1}^{n}\left(V_{i j}-V_{j}^{+}\right)^{2}} \quad S_{i}^{-}=\sqrt{\sum_{j=1}^{n}\left(V_{i j}-V_{j}^{-}\right)^{2}}
$$

There are separation distances $\left(\mathrm{S}_{\mathrm{i}}^{+}, \mathrm{S}_{\mathrm{i}}^{-}\right)$as many as of the positive ideal solutions and negative ideal solutions.

Step.7: The relative closeness (RC) to the ideal solution for each competitive design alternative is computed. $C_{i}^{*}$ takes values between $0 \leq C_{i}^{*} \leq 1$ interval.

$$
C_{i}^{*}=\frac{S_{i}^{-}}{S_{i}^{-}+S_{i}^{+}}
$$

When all stages are fulfilled, reaching the satisfactory results can be possible. At the end, total score shows the difference and ranking between all the alternatives.

The preference order of the alternatives, in accordance with their relative closeness to the ideal solution, is obtained. Higher value of relative closeness stands for higher preference order among generated design alternatives and is preferred (Lin, Wang, Chen, \& Chang, 2008).

\section{Findings}

In this study, Volume of Exports Per Capita, Normalized Trade Balance and Terms of Trade are used to measure foreign trade performance of OECD countries covering the period between the years 1999 and 2014. As a matter of example only the year of 2012 will be evaluated in this paper. In the year of 2012, the foreign trade performance of the 34 countries will be evaluated in following pages and others are calculated similarly.

First "Standard Decision Matrix" is constituted. "Volume of Exports Per Capita", "Normalized Trade Balance" and "Terms of Trade" is represented as "VEPC", "TB" and "TT" subsequently.

Step.1: Decision Matrix consisted according to three criteria.

Table 1: Standard decision matrix

\begin{tabular}{|l|l|l|l|l|}
\hline Country & Year & VEPC & TB & TT \\
\hline
\end{tabular}




\begin{tabular}{|c|c|c|c|c|}
\hline Australia & 2012 & 11293.21 & -0.00824 & $4.43 E+10$ \\
\hline Austria & 2012 & 19764.08 & -0.03449 & $-3.4 \mathrm{E}+09$ \\
\hline Belgium & 2012 & 40072.71 & 0.007694 & $-4.4 \mathrm{E}+09$ \\
\hline Canada & 2012 & 13108.93 & -0.02079 & $1.28 \mathrm{E}+10$ \\
\hline Chile & 2012 & 4473.7 & -0.01446 & $6.97 \mathrm{E}+12$ \\
\hline Czech Republic & 2012 & 14940.94 & 0.052367 & $-6.3 \mathrm{E}+10$ \\
\hline Denmark & 2012 & 18862.14 & 0.068614 & $-1.9 \mathrm{E}+10$ \\
\hline Estonia & 2012 & 12162 & -0.0585 & $-3.5 E+07$ \\
\hline Finland & 2012 & 13497.84 & -0.02267 & $-1.9 \mathrm{E}+09$ \\
\hline France & 2012 & 8664.05 & -0.08503 & $-1.5 \mathrm{E}+10$ \\
\hline Germany & 2012 & 17470.76 & 0.094174 & $-3.8 \mathrm{E}+10$ \\
\hline Greece & 2012 & 3195.011 & -0.28235 & $-1.1 \mathrm{E}+09$ \\
\hline Hungary & 2012 & 10440.14 & 0.042236 & $-5.5 \mathrm{E}+11$ \\
\hline Iceland & 2012 & 15788.6 & 0.029654 & $-5.2 \mathrm{E}+10$ \\
\hline Ireland & 2012 & 25457.95 & 0.300785 & $-4.1 \mathrm{E}+09$ \\
\hline Israel & 2012 & 7981.877 & -0.08844 & $-1.2 \mathrm{E}+09$ \\
\hline Italy & 2012 & 8419.691 & 0.012836 & $-1.8 \mathrm{E}+10$ \\
\hline Japan & 2012 & 6260.259 & -0.05181 & $-6.5 \mathrm{E}+12$ \\
\hline Korea, Republic of & 2012 & 10956.43 & 0.026498 & $-3.6 \mathrm{E}+13$ \\
\hline Luxembourg & 2012 & 35471.69 & -0.18779 & $8.09 \mathrm{E}+08$ \\
\hline Mexico & 2012 & 3036.291 & -0.01309 & $-1.2 \mathrm{E}+11$ \\
\hline Netherlands & 2012 & 39115.22 & 0.055097 & $-8.9 \mathrm{E}+09$ \\
\hline New Zealand & 2012 & 8462.8 & -0.01256 & $-1.9 \mathrm{E}+09$ \\
\hline Norway & 2012 & 32071.27 & 0.296642 & $1.27 \mathrm{E}+11$ \\
\hline Poland & 2012 & 4870.168 & -0.0356 & $-8.4 \mathrm{E}+09$ \\
\hline Portugal & 2012 & 5524.541 & -0.10987 & $-8.6 \mathrm{E}+08$ \\
\hline Slovak Republic & 2012 & 14907.14 & 0.020336 & $-1.6 \mathrm{E}+09$ \\
\hline Slovenia & 2012 & 15634.5 & 0.001993 & $-6.1 E+08$ \\
\hline Spain & 2012 & 6312.395 & -0.06653 & $-1.6 \mathrm{E}+10$ \\
\hline Sweden & 2012 & 18104.66 & 0.023484 & $-1.2 \mathrm{E}+10$ \\
\hline Switzerland & 2012 & 39073.33 & 0.027124 & $-4.5 \mathrm{E}+09$ \\
\hline Turkey & 2012 & 2057.538 & -0.21615 & $-4.7 \mathrm{E}+09$ \\
\hline United Kingdom & 2012 & 7422.131 & -0.18766 & $-1.3 \mathrm{E}+09$ \\
\hline United States & 2012 & 4920.855 & -0.2037 & $-1.9 \mathrm{E}+10$ \\
\hline
\end{tabular}

Step.2: Equation 2 is used to normalize the Decision Matrix on Table1. NVEPC, NTB, NTT are represent for Normalized Volume of Exports per Capita, Normalized Trade Balance and Normalized Terms of Trade. 
11293.21

$\frac{\sqrt{\left.11293.21^{2}+19764.08^{2} \ldots . .+44929.855^{2}\right)}}{n}$

Table 2: Normalized decision matrix

\begin{tabular}{|c|c|c|}
\hline NVEPC & NTB & NTT \\
\hline 0.106181 & -0.01185 & 0.001195 \\
\hline 0.185825 & -0.04961 & $-9.2 \mathrm{E}-05$ \\
\hline 0.376771 & 0.011069 & -0.00012 \\
\hline 0.123252 & -0.02991 & 0.000346 \\
\hline 0.042063 & -0.0208 & 0.188008 \\
\hline 0.140477 & 0.075334 & -0.00169 \\
\hline 0.177345 & 0.098708 & -0.00052 \\
\hline 0.114349 & -0.08415 & $-9.3 \mathrm{E}-07$ \\
\hline 0.126909 & -0.03262 & $-5.2 \mathrm{E}-05$ \\
\hline 0.081461 & -0.12233 & -0.00041 \\
\hline 0.164263 & 0.135478 & -0.00102 \\
\hline 0.03004 & -0.40619 & $-2.9 \mathrm{E}-05$ \\
\hline 0.09816 & 0.06076 & -0.01485 \\
\hline 0.148447 & 0.04266 & -0.0014 \\
\hline 0.23936 & 0.432707 & -0.00011 \\
\hline 0.075047 & -0.12722 & $-3.3 \mathrm{E}-05$ \\
\hline 0.079163 & 0.018465 & -0.00048 \\
\hline 0.05886 & -0.07454 & -0.17651 \\
\hline 0.103014 & 0.038119 & -0.96605 \\
\hline 0.333511 & -0.27015 & $2.18 \mathrm{E}-05$ \\
\hline 0.028548 & -0.01883 & -0.00323 \\
\hline 0.367768 & 0.079262 & -0.00024 \\
\hline 0.079569 & -0.01806 & $-5.2 \mathrm{E}-05$ \\
\hline 0.30154 & 0.426746 & 0.003416 \\
\hline 0.04579 & -0.05121 & -0.00023 \\
\hline 0.051943 & -0.15805 & $-2.3 \mathrm{E}-05$ \\
\hline 0.140159 & 0.029255 & $-4.3 \mathrm{E}-05$ \\
\hline 0.146998 & 0.002867 & $-1.6 \mathrm{E}-05$ \\
\hline 0.05935 & -0.09571 & -0.00043 \\
\hline 0.170223 & 0.033784 & -0.00032 \\
\hline 0.367374 & 0.039021 & -0.00012 \\
\hline 0.019345 & -0.31095 & -0.00013 \\
\hline 0.069784 & -0.26997 & $-3.5 \mathrm{E}-05$ \\
\hline 0.046267 & -0.29305 & -0.00051 \\
\hline
\end{tabular}

Step.3: Comparison Matrix is composed by experts' opinions. After normalization of the comparison matrix, mean values of every row shows the needed weights of every criteria but the comparison matrix must be consistent to be accepted (Bulut \& Soylu, 2009). 
Table 3: Comparison matrix with expert opinions

\begin{tabular}{|l|l|l|l|}
\hline & TB & TT & VEPC \\
\hline TB & 1.0 & 3 & 7 \\
\hline TT & 0.33 & 1.0 & 5 \\
\hline VEPC & 0.14 & 0.2 & 1.0 \\
\hline
\end{tabular}

To get consistency and weights that are going to be multiplied with Normalized Decision Matrix's columns, Super Decisions Program is used. The weights are shown in the table 4.

Table 4: Weights of the criteria

\begin{tabular}{|l|l|l|}
\hline Inconsistency & 0.06239 & \\
\hline Name & Normalized & Idealized \\
\hline TB & 0.6491 & 1.0 \\
\hline TT & 0.2789 & 0.429 \\
\hline VEPC & 0.0719 & 0.110 \\
\hline
\end{tabular}

As seen as on table 4 , the most important criterion for measuring international trade performance is seemed as TB (0.6491). Afterwards, TT (0.2789) and finally VEPC (0.0719) follow subsequently. Consistency rate has been found 0.06239 and it implies that importance degrees of criteria are consistent. Consequently, weights $\mathrm{w}_{1}=0.0719$. $\mathrm{w}_{2}=0.6491$. $\mathrm{w}_{3}=0.2789$ are accepted.

Step.4: The decision matrix's columns are multiplied by $\mathrm{w}_{1}, \mathrm{w}_{2}$, and $\mathrm{w}_{3}$ values subsequently and the table 5 is obtained. NVEPCV , NTBV, NTTV are represent for Weighted Normalized Volume of Exports per Capita, Weighted Normalized Trade Balance and Weighted Normalized Terms of Trade.

Table 5: Weighted normalized matrix

\begin{tabular}{|l|l|l|}
\hline NVEPCV & NTBV & NTTV \\
\hline 0.007637 & -0.00769 & 0.000333342 \\
\hline 0.013366 & -0.0322 & $-2.5746 \mathrm{E}-05$ \\
\hline 0.0271 & 0.007185 & $-3.3177 \mathrm{E}-05$ \\
\hline 0.008865 & -0.01942 & $9.63808 \mathrm{E}-05$ \\
\hline 0.003025 & -0.0135 & 0.052445797 \\
\hline 0.010104 & 0.048901 & -0.00047217 \\
\hline 0.012756 & 0.064073 & -0.00014374 \\
\hline 0.008225 & -0.05463 & $-2.6022 \mathrm{E}-07$ \\
\hline 0.009128 & -0.02117 & $-1.4638 \mathrm{E}-05$ \\
\hline 0.005859 & -0.07941 & -0.00011501 \\
\hline 0.011815 & 0.087941 & -0.00028382 \\
\hline 0.002161 & -0.26366 & $-8.0376 \mathrm{E}-06$ \\
\hline 0.00706 & 0.03944 & -0.00414112 \\
\hline 0.010677 & 0.027692 & -0.00038977 \\
\hline 0.017217 & 0.280878 & $-3.0524 \mathrm{E}-05$ \\
\hline 0.005398 & -0.08258 & $-9.217 \mathrm{E}-06$ \\
\hline & & \\
\hline & & \\
\hline
\end{tabular}




\begin{tabular}{|l|l|l|}
\hline 0.005694 & 0.011986 & -0.0001341 \\
\hline 0.004234 & -0.04838 & -0.04923938 \\
\hline 0.00741 & 0.024744 & -0.26948287 \\
\hline 0.023989 & -0.17536 & $6.08582 \mathrm{E}-06$ \\
\hline 0.002053 & -0.01223 & -0.00090079 \\
\hline 0.026453 & 0.05145 & $-6.7105 \mathrm{E}-05$ \\
\hline 0.005723 & -0.01173 & $-1.4503 \mathrm{E}-05$ \\
\hline 0.021689 & 0.277009 & 0.000952783 \\
\hline 0.003294 & -0.03324 & $-6.3219 \mathrm{E}-05$ \\
\hline 0.003736 & -0.1026 & $-6.4901 \mathrm{E}-06$ \\
\hline 0.010081 & 0.01899 & $-1.196 \mathrm{E}-05$ \\
\hline 0.010573 & 0.001861 & $-4.5952 \mathrm{E}-06$ \\
\hline 0.004269 & -0.06213 & -0.00012124 \\
\hline 0.012244 & 0.02193 & $-8.8328 \mathrm{E}-05$ \\
\hline 0.026424 & 0.025329 & $-3.3567 \mathrm{E}-05$ \\
\hline 0.001391 & -0.20184 & $-3.508 \mathrm{E}-05$ \\
\hline 0.005019 & -0.17524 & $-9.8762 \mathrm{E}-06$ \\
\hline 0.003328 & -0.19022 & -0.00014116 \\
\hline
\end{tabular}

Step.5: The highest and the lowest value of the every column of the weighted normalized decision matrix is taken to find positive ideal $\mathrm{A}+$ and negative $\mathrm{A}-\mathrm{set}$. Because we have 3 criteria, there will be three values for each $A+$ and $A-$ sets. $A^{+}=(0.027100,0.280878$, $0.052446), \mathrm{A}^{-}=(0.001391,-0.26366,-0.26948)$

Step.6: For every alternative the distances from positive $(\mathrm{S}+)$ and negative ideal solutions (S-) are calculated according to equation (5):

$$
\begin{aligned}
& S_{i}^{+}=\sqrt{(0.0076-0.027)^{2}+(0.087-0.28)^{2}+(0.0003-0.05)^{2}}=0.2938 \\
& S_{i}^{-}=\sqrt{(0.0076-0.001)^{2}+(0.087-0.26)^{2}+(0.0003-0.27)^{2}}=0.3819
\end{aligned}
$$

$\boldsymbol{S}_{\boldsymbol{i}}^{+}=\{0.293885,0.317745,0.278679,0.305368,0.295364,0.238542,0.223552,0.340102$, $0.3071,0.364716,0.200595,0.54763,0.248789,0.259161,0.053399,0.367867,0.274819$, $0.345364,0.411862,0.45925,0.29897,0.23536,0.298037,0.051921,0.319367,0.387748$, $0.267632,0.284384,0.347762,0.26464,0.260883,0.486245,0.459654,0.474621\}$

$\boldsymbol{S}_{\boldsymbol{i}}^{-}=\{0.371968,0.355421,0.382914,0.363848,0.407702,0.412479,0.424363, \quad 0.341122$, $0.362593,0.326389,0.442947,0.269476,0.402877,0.396718, \quad 0.607766,0.324688$, $0.385422,0.307994,0.28847,0.284487,0.36791,0.415343, \quad 0.368923,0.604875,0.35452$, $0.313952,0.390619,0.378426,0.336422,0.392753,0.395912,0.276449,0.283633$, $0.279182\}$

Step7: The relative closeness (RC) to the ideal solution for each competitive design alternative is computed. $C_{i}^{*}$ values are in between $0 \leq C_{i}^{*} \leq 1$ interval and if the result is close to 1 , it indicates the closeness to the ideal solution. $C_{i}$ 's can be calculated as equation below:

$$
C_{1}=\frac{0.293885}{(0.371968+0.293885)}=0.558634
$$


$\mathrm{C}_{\mathrm{i}}=\{0.558634,0.527984,0.578776,0.543693,0.579892,0.633588,0.654967,0.500748$, $0.541432,0.472271,0.688295,0.329793,0.618227,0.604864,0.919235,0.468826,0.583759$, $0.471402,0.411905,0.38251,0.551688,0.638297,0.553142,0.920948,0.526083,0.447416$, $0.59342,0.570941,0.491713,0.59744,0.602794,0.362464,0.381593,0.370365\}$

Final Decision: Alternatives are ranked by their biggest value to the smallest. By this way, best alternative can be chosen (Dumanoğlu, 2010).

Table 6: The rank of the foreign trade performances for the 2012, 2013 and 2014

\begin{tabular}{|c|c|c|c|c|c|c|c|c|}
\hline Country & 2012 & Rank & Country & 2013 & Rank & Country & 2014 & Rank \\
\hline Australia & 0.558 & 16 & Australia & 0.593 & 11 & Australia & 0.601 & 14 \\
\hline Austria & 0.527 & 21 & Austria & 0.534 & 22 & Austria & 0.575 & 18 \\
\hline Belgium & 0.578 & 14 & Belgium & 0.590 & 13 & Belgium & 0.618 & 13 \\
\hline Canada & 0.543 & 19 & Canada & 0.541 & 20 & Canada & 0.589 & 16 \\
\hline Chile & 0.579 & 13 & Chile & 0.580 & 14 & Chile & 0.668 & 7 \\
\hline Czech Rep. & 0.633 & 6 & Czech Rep. & 0.645 & 6 & Czech Rep. & 0.679 & 5 \\
\hline Denmark & 0.654 & 4 & Denmark & 0.655 & 5 & Denmark & 0.666 & 9 \\
\hline Estonia & 0.500 & 23 & Estonia & 0.485 & 25 & Estonia & 0.506 & 25 \\
\hline Finland & 0.541 & 20 & Finland & 0.536 & 21 & Finland & 0.568 & 20 \\
\hline France & 0.472 & 25 & France & 0.463 & 26 & France & 0.492 & 26 \\
\hline Germany & 0.688 & 3 & Germany & 0.702 & 3 & Germany & 0.737 & 3 \\
\hline Greece & 0.329 & 34 & Greece & 0.319 & 34 & Greece & 0.326 & 34 \\
\hline Hungary & 0.618 & 7 & Hungary & 0.609 & 9 & Hungary & 0.622 & 12 \\
\hline Iceland & 0.604 & 8 & Iceland & 0.560 & 16 & Iceland & 0.548 & 22 \\
\hline Ireland & 0.919 & 2 & Ireland & 0.893 & 2 & Ireland & 0.872 & 1 \\
\hline Israel & 0.468 & 27 & Israel & 0.490 & 24 & Israel & 0.523 & 24 \\
\hline Italy & 0.583 & 12 & Italy & 0.617 & 8 & Italy & 0.667 & 8 \\
\hline Japan & 0.471 & 26 & Japan & 0.385 & 30 & Japan & 0.473 & 27 \\
\hline Korea Rep. & 0.411 & 29 & Korea Rep. & 0.433 & 29 & Korea Rep. & 0.444 & 29 \\
\hline Lux. & 0.382 & 30 & Lux. & 0.361 & 31 & Lux. & 0.400 & 31 \\
\hline Mexico & 0.551 & 18 & Mexico & 0.543 & 19 & Mexico & 0.563 & 21 \\
\hline Netherland & 0.638 & 5 & Netherland & 0.655 & 4 & Netherland & 0.682 & 4 \\
\hline New Zealand & 0.553 & 17 & New Zealand & 0.560 & 17 & New Zealand & 0.575 & 19 \\
\hline Norway & 0.920 & 1 & Norway & 0.895 & 1 & Norway & 0.870 & 2 \\
\hline Poland & 0.526 & 22 & Poland & 0.555 & 18 & Poland & 0.579 & 17 \\
\hline Portugal & 0.447 & 28 & Portugal & 0.448 & 27 & Portugal & 0.464 & 28 \\
\hline Slovak Rep. & 0.593 & 11 & Slovak Rep. & 0.596 & 10 & Slovak Rep. & 0.625 & 11 \\
\hline Slovenia & 0.570 & 15 & Slovenia & 0.577 & 15 & Slovenia & 0.629 & 10 \\
\hline
\end{tabular}




\begin{tabular}{|l|l|l|l|l|l|l|l|l|}
\hline Spain & 0.491 & 24 & Spain & 0.518 & 23 & Spain & 0.524 & 23 \\
\hline Sweden & 0.597 & 10 & Sweden & 0.593 & 12 & Sweden & 0.597 & 15 \\
\hline Switzerland & 0.602 & 9 & Switzerland & 0.639 & 7 & Switzerland & 0.673 & 6 \\
\hline Turkey & 0.362 & 33 & Turkey & 0.324 & 33 & Turkey & 0.361 & 33 \\
\hline UK & 0.381 & 31 & UK & 0.445 & 28 & UK & 0.412 & 30 \\
\hline USA & 0.370 & 32 & USA & 0.357 & 32 & USA & 0.372 & 32 \\
\hline
\end{tabular}

In the table below, all the periods of countries has been ranked from best foreign performance to worst.

Table 7: Final Ranking of countries between 1999 and 2014

\begin{tabular}{|c|c|c|c|c|c|c|c|c|}
\hline Rank & Country & Score & Rank & Country & Score & Rank & Country & Score \\
\hline 1 & Norway & 38 & 13 & Canada & 217 & 25 & Israel & 366 \\
\hline 2 & Ireland & 42 & 14 & Czech Rep. & 222 & 26 & Poland & 383 \\
\hline 3 & Germany & 95 & 15 & Hungary & 252 & 27 & Estonia & 412 \\
\hline 4 & Denmark & 133 & 16 & Italy & 257 & 28 & Luxembourg & 420 \\
\hline 5 & Netherland & 139 & 17 & Slovenia & 284 & 29 & Spain & 430 \\
\hline 6 & Sweden & 147 & 18 & Slovak Rep. & 285 & 30 & UK & 439 \\
\hline 7 & Chile & 151 & 19 & Austria & 297 & 31 & Portugal & 472 \\
\hline 8 & Japan & 163 & 20 & Iceland & 309 & 32 & Turkey & 478 \\
\hline 9 & Finland & 185 & 21 & Australia & 313 & 33 & USA & 494 \\
\hline 10 & Korea Rep. & 185 & 22 & Mexico & 321 & 34 & Greece & 515 \\
\hline 11 & Switzerland & 185 & 23 & New Zealand & 328 & & & \\
\hline 12 & Belgium & 210 & 24 & France & 353 & & & \\
\hline
\end{tabular}

\section{Conclusion}

When all the period from 1999 to 2014 examined, the best performing country is Norway while the worst performing country is seen as Greece among OECD countries. The first five countries which have the best foreign trade performance are Norway, Ireland, Germany, Denmark and Netherlands subsequently and the last five countries which have the worst foreign performance are Greece, United States, Turkey, Portugal and United Kingdom subsequently.

\section{Discussion}

Investigating the economic performance of countries has received the the growing interest of researchers since 1990s. Most of the empirical research in this regard has focused on developing countries because of their structural weaknesses and instability. Understanding the foreign performance of OECD group of countries is more important for policy makers in the global context.

In this study, we perform TOPSIS method to evaluate benchmarking performance in OECD countries in international trade. The set of results suggest that the best performing country is Norway while the worst performing country in Greece over the 1999-2014 period. The worst three performers, Turkey, USA and Greece have undergone major financial crises 
over the last 20 years which has led to the imposition of restrictive trade policies. The ongoing sovereign debt crisis in the EU has also the same impact not only on these countries but also some other worst performer OECD countries such as Spain, UK and Portugal (see table.7). The success of the best performing countries in international trade such as Norway, Ireland, Germany, Denmark and Netherland has been determined by their overall economic performance as well as foreign trade policies. The United States has relatively high tariffs and non-tariff trade barriers of imports from developing countries. As a whole, the restrictions have a great impact on trade balance which in turn ranking of the foreign trade performances. Furthermore, the existence of an asymmetry according to economic performance and trade barriers of the sampling countries should be noted. Beside these, USA and UK have been suffering from trade deficits almost for two decades because of their overvalued exchange rates and increasing consumer spending despite they are biggest economies of the world.

\section{Implications}

As it can be seen from findings, more productive and innovative countries are leaders in international trade. Especially, socioeconomic factors such as human rights, education system, health care and transparency of open state become prominent as so in Nordic countries, Ireland and Germany. For this reason, governments should give priority to develop socioeconomic welfare to constitute competitive economy.

This paper can be expanded by changing countries, periods and importance weights which are attached to criteria and the result which is acquired from TOPSIS analyze, may be controlled and supported by the other multivariate decision methods.

\section{References}

Alvarez, R., \& López, R. a. (2005). Exporting and performance: Evidence from Chilean plants. Canadian Journal of Economics, 38(4), 1384-1400. http://doi.org/10.1111/j.00084085.2005.00329.x

Araujo, R. A., \& Trigg, A. B. (2015). A neo-Kaldorian approach to structural economic dynamics. Structural Change and Economic Dynamics, 33, 25-36. http://doi.org/10.1016/j.strueco.2015.02.002

BULUT, K., \& SOYLU, B. (2009). Öğretim Üyelerinin iş Yükü Seviyelerinin Analitik A $\breve{g}$ Modeli ile Değerlendirilmesi: Mühendislik Fakültesinde Bir Uygulama. Erciyes Üniversitesi Fen Bilimleri Dergisi, 25((1-2)), 150-167.

Dumanoğlu, S. (2010). Financial Performance Evaluation of Cement, 5(5), 323-340.

Eleren, A., \& Karagül, M. (2008). 1986-2006 Türkiye Ekonomisinin Performans Değerlendirmesi. Celal Bayar Üniversitesi İ.İ.B.F Dergisi, 15(1), 1-14.

Eyüboğlu, K. (2015). Comparison of Developing Countries' Macro Performances with AHP and TOPSIS Methods. Çankırı Karatekin Üniversitesi Íktisadi ve İdari Bilimler Fakültesi Dergisi, 2016(1), 1-16.

Grossman, G. M., \& Helpman, E. (1989). Product Development and International Trade. Journal of Political Economy, 97(6), 1261-1283.

Iapadre, P. L. (2001). Measuring international specialization. International Advances in Economic Research, 7(2), 173-183. http://doi.org/10.1007/BF02296007

Jeníček, V. (2003). World economy globalisation. HC Beck, Prague (in Czech).

Krepl, V., \& Jeníček, V. (2009). The role of foreign trade and its effects. Agric. Econ.-Czech, 55(5), 211-220.

Lichtenberg, F. R., Pottelsberghe, B. Van, \& Potterie, D. (1998). International R \& D spillovers : A comment. European Economic Review, 42(8), 1483-1491.

Lin, M. C., Wang, C. C., Chen, M. S., \& Chang, C. A. (2008). Using AHP and TOPSIS approaches in customer-driven product design process. Computers in Industry, 59(1), 
17-31. http://doi.org/10.1016/j.compind.2007.05.013

Majerová, I., \& Nevima, J. (2015). Exploring regional aspects of competitiveness in the selected countries of Visegrad Group Plus. Silesian University, School of Business Administration Working Papers (Vol. 17).

Mandic, K., Delibasic, B., Knezevic, S., \& Benkovic, S. (2014). Analysis of the financial parameters of Serbian banks through the application of the fuzzy AHP and TOPSIS methods. Economic Modelling, 30-37. http://doi.org/10.1016/j.econmod.2014.07.036

Mangır, F., \& Erdoğan, S. (2011). Comparison of Economic Performance Among Six Countries in Global Financial Crisis: The Application of Fuzzy TOPSIS Method. Economics, Management \& Financial Markets, 6(2), 122-136.

Mendoza, E. G. (1997). Terms-of-trade uncertainty and economic growth. Journal of Development Economics, 54(2), 323-356. http://doi.org/10.1016/S03043878(97)00046-1

Özcan, T., Elebi, N., \& Esnaf, A. (2011). Comparative analysis of multi-criteria decision making methodologies and implementation of a warehouse location selection problem. Expert Systems with Applications, 38(8), 9773-9779. http://doi.org/10.1016/j.eswa.2011.02.022

Scott, B. R., \& Lodge, G. C. (1985). US competitiveness in the world economy. The International Executive, 27(1), 26.

Supçiller, A. A., \& Çapraz, O. (2011). Ahp-topsis yöntemine dayali tedarikçi seçimi uygulamasi. Ekonometri ve Istatistik Dergisi, 13, 1-22.

Teixeira, A. A. C., \& Fortuna, N. (2010). Human capital, R\&amp;D, trade, and long-run productivity. Testing the technological absorption hypothesis for the Portuguese economy, 1960-2001. Research Policy, 39(3), 335-350. http://doi.org/10.1016/j.respol.2010.01.009

Urfalioğlu, F., \& Genç, T. (2013). Çok Kriterli Karar Verme Teknikleri ile Türkiye'nin Ekonomik Performansının Avrupa Birliği Üye Ülkeleri ile Karşılaştırılması. Marmara University Journal of Economic \& Administrative Sciences, 35(2), 329-360.

Wanke, P., Azad, M. D. A. K., \& Barros, C. P. (2016). Predicting efficiency in Malaysian Islamic banks: A two-stage TOPSIS and neural networks approach. Research in International Business and Finance, 36, 485-498. http://doi.org/10.1016/j.ribaf.2015.10.002

Zavadskas, E. K., \& Turskis, Z. (2011). Multiple criteria decision making (MCDM) methods in economics: an overview. Technological and Economic Development of Economy, 17(2), 397-427. http://doi.org/10.3846/20294913.2011.593291 